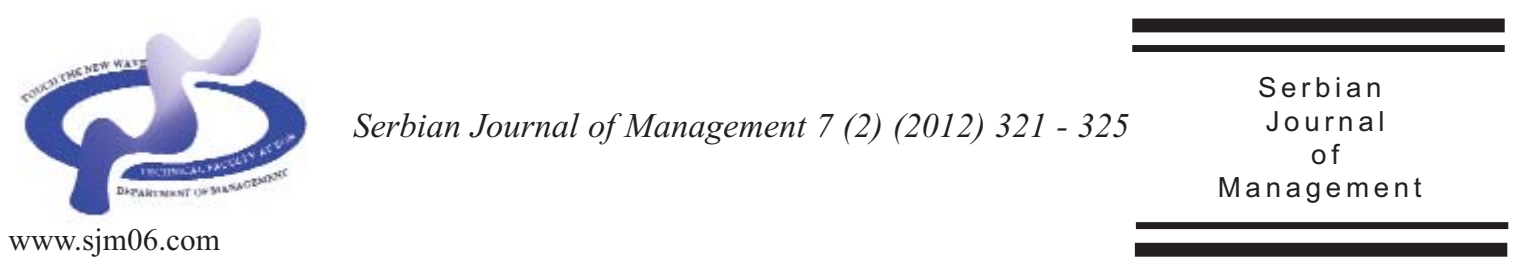

Short Communication

\title{
ADAPTATION OF THE HP LIFE PROGRAM FOR PROMOTION OF THE ENTREPRENEURSHIP AMONG YOUNG PEOPLE
}

\author{
Ivan Mihajlovič ${ }^{*}$ Živan Živković and Đorđe Nikolić \\ University of Belgrade, Technical faculty in Bor, \\ Vojske Jugoslavije 12, 19210 Bor, Serbia
}

(Received 10 September 2012; accepted 15 October 2012)

\begin{abstract}
This text is dealing with attempt of Management department, of Technical faculty in Bor, to develop and further sustain the „entrepreneurial spirit“among young people. The subject of the paper is the HP LIFE program, in which Technical faculty in Bor is the only partner institution from Serbia. Besides up-to-date IT equipment obtained by Hewlett Packard in previous phases of this project, during 2012 this project was financially sustained by the Serbian institution „Centre for promotion of science“. This support will increase the scope of project activities during this year, including new target groups.
\end{abstract}

Keywords: HP LIFE, entrepreneurial skills, training

\section{INTRODUCTION}

There are 5.5 million 15 - to 24-year-olds without a job in the EU, a rate of $22.4 \%$ in 2012, has risen up from $15 \%$ in early 2008 . But the overall figures mask huge national and regional disparities. While half of young people in Spain and Greece are out of work, in Germany, Austria and the Netherlands it is only one in 10. In a further six EU countries, youth unemployment is around 30\%. Of those in work, $44 \%$ are on temporary contracts (The Guardian, 2012). In USA there are more than 10 million of young people seeking for job (US bureau of labor statistics, 2012). The decline has been particularly sharp since 2000, with employment for 16-to-19-year olds falling to the lowest level since World War II. In countries of West Balkan, the rate of youth

\footnotetext{
*Corresponding author: imihajlovic@tf.bor.ac.rs

DOI:10.5937/sjm 7-2745
} 
unemployment is even higher. This is especially a case with countries outside the EU, such is Serbia (Obradović et al, 2012).

Considering such global trend, one of the Worlds most social responsible companies, Hewlett Packard (HP) initiated a program called HP Learning Initiative for Entrepreneurs (HP LIFE). HP LIFE is a global program that trains students, entrepreneurs, and small business owners to apply IT and business skills, so they can establish and grow a business, build successful companies and create jobs. Based on face-to-face trainings, tools and eLearning this program address educational needs improve and strengthen skills and enable attendants to move forward.

In 49 countries around the globe, HP LIFE works with more than 340 partner organizations. Management department of Technical faculty in Bor, University of Belgrade, initiated the partnership with this program during 2008. At that time, management department become a partner organization in another program that was called GET IT (Mihajlović and Živković, 2008). This program was a predecessor of much larger LIFE program. Technical faculty in Bor continued its participation on this program. This way, technical faculty in Bor is the only institution in Serbia which is included in this program (HP LIFE official site, 2012).

\section{HP LIFE AT TECHNICAL FACULTY IN BOR}

Since the beginning of the GET IT program, and now with LIFE, completely training was incorporated in the curriculum of the Management department of Technical faculty in Bor. The training is included in the subject Management Information Systems, which is dedicated to BSc students of 3rd year.

LIFE training consists of interactive courses that deal with practical IT solutions for daily business challenges. The core element is a innovative curriculum called LIFE curriculum that bridges the divide between pure business skills courses and technical skills courses. LIFE fills the gap between business and standard IT courses. Also, the course brings the necessary knowledge of issues how to start, sustain and further develop own business in the frame of micro entrepreneurial venture to SMEs. The modules explore how different IT solutions can address common business challenges in the areas of Management and Operations, Finances, Communication, and Marketing. Students are also in a better position to evaluate their skills and to identify their own needs for further training and development. Basic modules of the LIFE training are presented in Figure 1. Each of four modules is further divided in to 5 levels. Levels are structured based on previous knowledge of trainees. First two levels (imagine and plan) are for completely beginners such are elementary school students. Third and fourth levels are for attendants whose knowledge is adequate to high school students, while the last one is for advanced students at the university level.

The approach of LIFE curriculum is far from traditional lecturing. Its approach is totally new and innovative and this way making difference with its originality. Another ingredient of the LIFE curriculum is the use of experiential learning methodology. The experiential learning cycle works as follows:

First, participants are provided with new information; second, they process the 


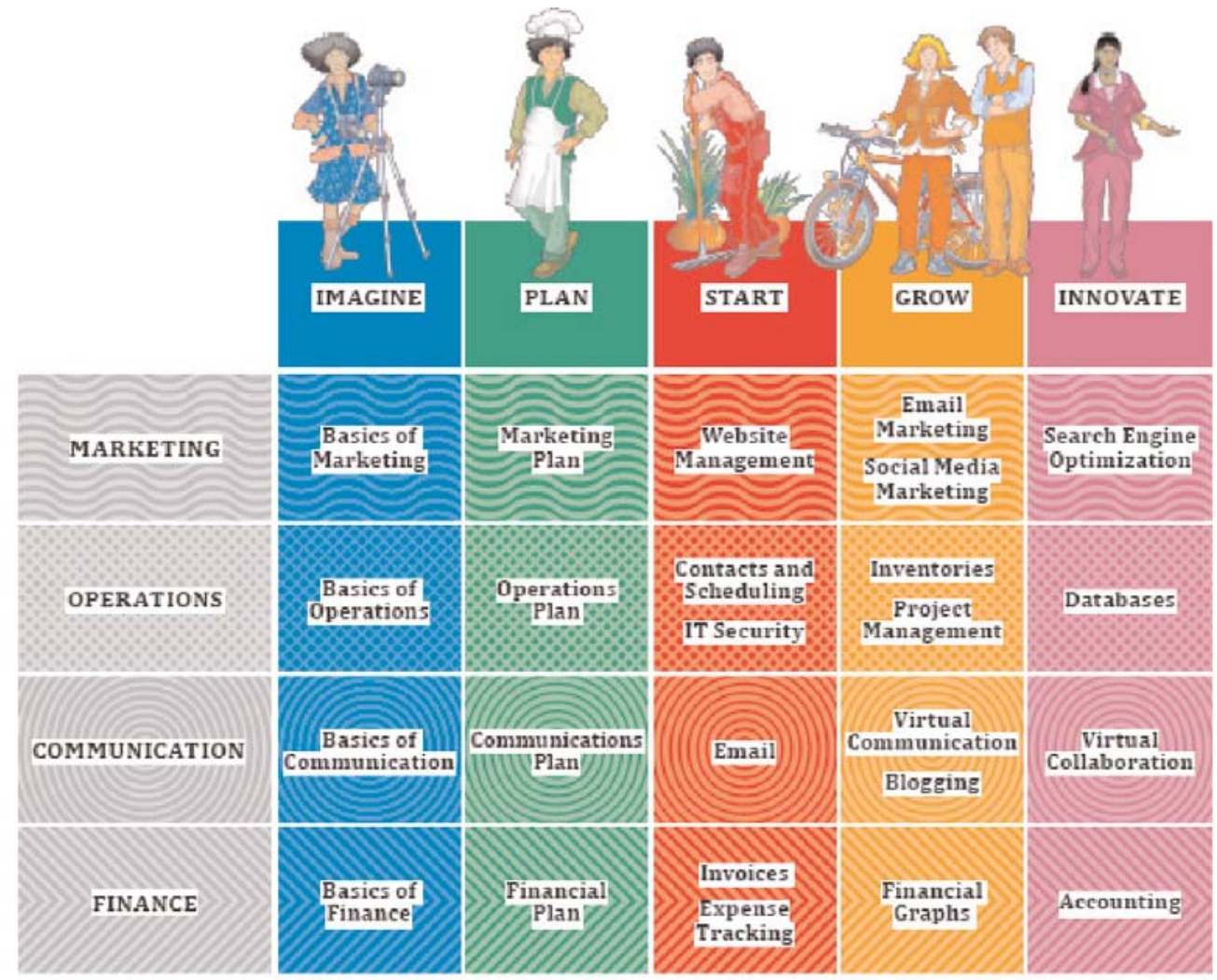

Figure 1. LIFE topics matrix [Source: HP Life - Trainers Handbook]

information in a hands-on experience; third, they reflect on the experience; and fourth, they apply what they have learned. Research shows that adults learn best in this hands-on way (Mihajlović \& Živković, 2008).

As one of the participating organizations, Technical faculty in Bor received a grant of HP equipment (10 modern lap tops, HP Wireless Access Point, 1 HP Pro Curve Switch 408, digital projector, and Mobile Net cart). Also, as one of the registered training centers, TF Bor has unlimited access to all documentation which is required for conducting the trainings. The documentation includes: Students handbooks, Trainer handbooks, question cards, slides, and demo and exercise files. All this material is constantly updated and available to registered training centers representatives.
Also, Technical faculty in Bor has approach to electronic learning platform which is sustained by the HP LIFE program.

\section{FURTHER DEVELOPMENT}

Since the beginning of this program, representatives of Management department, of technical faculty in Bor, were seeking for local recognition of this program by representatives of local and state institutions. This would off course mean much, since it would enable expansion of this program outside from the border of the Faculty.

Fortunately, during the year 2012, this program was sustained by Serbian center for promotion of science (http://www.cpn.rs). The project which includes LIFE program 
workshops in high schools in Bor region was financially supported by this institution. This enables planning the workshops with high school students and further promotion of the HP LIFE curriculum in Serbia.

\subsection{The issue of the project}

The fact that large number of unemployed young people in Bor region and even Serbia could easily become self employed was main motivation for starting this project. Increasing their competitiveness after realization of the project will result with rapid development of micro enterprises.

Reason for selection of target groups among high school and the university students is based on the fact that the future of this region as well as the future of the whole country is highly depending on developing SMOs sector. Young population of Serbia should become able to develop its own entrepreneurial way of thinking. Older generations of Serbian workers are already developed in the spirit of becoming a employee in large industrial sector and companies like those that were active in this country in the past. It is not an easy job to transfer their opinion toward the entrepreneurial way of life and thinking. However, young people did not have this opportunity to start their careers in large industrial facilities, since the number of such companies sharply decreased during last 20 years in Serbia. This way, they can readily be comprised with this project activity. The final goal is to develop required skills for starting and running own business in the frame of SMO and even microentrepreneurial ventures. This project is offering the use of the same technology which they regularly use (e.g. computers, social networks, groups, blogs, etc) to increase their skills and at the same time their employability as well as self employability. Accordingly, younger generations will learn how to use IT technology in other purposes besides everyday entertainment. However, the most important issue of this project is development of entrepreneurial way of thinking among young generation in Serbia.

Acknowledgement: The project "Adaptation of the HP Life Program curriculum for promotion of the youth entrepreneurship" is financially supported by the Center for promotion of science, Serbia.

\section{References}

Mihajlović, I., Živković, Ž., Project GETIT: Serbia. Serbian Journal of Management, 3 (2) (2008), 223 - 235.

Obradović, S., Fedajev, A., Nikolić, Đ., Analysis of Business Environment Using the Multi-Criteria Approach - Case of Balkan's Transition Economies, Serbian Journal of Management, 7 (1) (2012), 37 - 52.

Web references:

The Guardian: http:/www.guardian.co.uk/business/2012/ap r/16/european-youth-unemployment-soars

US bureau of labor statistics: http://www.huffingtonpost.com/news/usbureau-of-labor-statistics

HP LIFE official site: http://www.lifeg lob a 1 . org/e n / A B O U T - T H E PROGRAM/Find-a-Center

Center for promotion of science of Serbia: http://www.cpn.rs/ 


\title{
АДАПТАЦИЈА КУРИКУЛУМА ЗА ПРИМЕНУ "НР LIFE" ПРОГРАМА ЗА ПРОМОЦИЈУ ОМЛАДИНСКОГ ПРЕДУЗЕТНИШТЦА
}

\author{
Иван Михајловић, Живан Живковић и Ђорђе Николић
}

\section{Извод}

Овај текст се бави покушајем Одсека за менаџмент, Техничког факултета у Бору, да утиче на развој и одржање "предузетничког духа" међу младима. Предмет публикације је HP LIFE програм, у којем је Технички факултет у Бору једина партнерска институција у Србији. Поред савремене ИТ опреме која је добијена као донација Hewlett Packard-a у претходним фазама овог пројекта, током 2012. пројекат је финансијски подржан од стране Центра за промоцију науке (Београд, Србија). Ова подршка ће проширити опсег пројектних активнсоти током ове године, укључујући нове циљне групе као крајње кориснике пројекта.

Кључне речи: HP LIFE, предузетничке вештине, тренинг 